\title{
Effectiveness of Receivables Management in Increasing Sales Profit on Credit
}

\author{
Yayuk Indah Wahyuning Tyas \\ Faculty of Economics, Panca Marga University Probolinggo \\ Email: ayukupm@.ac.id
}

https://doi.org/10.30741/wiga.v10i1.529

\section{A R T I C L E IN F O}

Date of entry:

02 February 2020

Revision Date:

2 March 2020

Date Received:

26 March 2020

\begin{abstract}
A B S T R A C T
This study aims to find out how the results of the analysis of the effectiveness of accounts receivable management in increasing profits through the implementation of policies on the sale of bags on credit at the Vion City Store Probolinggo, productive/profitable or ineffective/unprofitable. This type of research is descriptive research with quantitative methods-primary data sources in the form of interviews and secondary data that is financial statements. Data collection techniques used are observation and data documentation in Vion City Store Probolinggo. The percentage of profit from 2019 until 2019 always decreases to $27.79 \%$ in 2019 this is because the average receivables from 2019 to 2019 always increase. Hence, it affects the operating costs (investment), which has grown from the year 2019 until 2019.
\end{abstract}

Keywords: Receivables Management, Profit, Activity Ratio Analysis

\section{INTRODUCTION}

The development of the increasingly complex business world requires business actors to be able to maintain the existence of their businesses, given that business competition is also getting tighter. So companies must have a strategy to survive and compete in the business world. The main purpose of the company is to earn profits and maintain the survival of the company. Profit is obtained if the amount of income received by the company exceeds the costs incurred. Given the increasingly competitive business competition, the company's ability to achieve profits is also constrained, it is necessary to do a strategy to increase profits, one of which is done by increasing sales volume both cash and credit sales. In general, companies will prefer cash sales rather than credit, but there are some companies that prefer credit sales, but competitive pressures have forced most companies to offer credit sales.

The credit sales system is one of the ways taken by the company to increase sales volume. With this sales system, it is expected that product or service sales transactions can increase, in addition to that the company can also get new consumers so that the company's profits will also increase indirectly. Credit sales activities have a good impact, namely the emergence of receivables. Trade 
receivables or receivable accounts occur when companies sell goods or services on credit, not cash (Luke, 2008: 395).

Management of receivables begins with the decision whether the company will provide credit or not, then receivables that arise must be monitored so as not to exceed the allowable limit, effective management of receivables also affects the level of profit and risk of the company (Luke, 2008: 395). Lukman (2011: 274) argues that receivables are a form of investment that is large enough in most companies, then with better management of receivables will be able to provide benefits and substantial savings for the company, the overall corporate goals with respect to the management of receivables It should not be emphasized on the speed of collection of receivables, but also must consider the cost-benefit trade-off (profit and loss) that may arise in other aspects of management of receivables such as policies in collecting receivables.

Luke (2008: 395) believes that accounts receivable or receivable accounts occur when companies sell goods/services on credit, not cash. According to Lukman (2011: 242), receivables are an important item in the company because by holding a policy of selling on credit to consumers, this will usually be followed by a greater sales volume compared to the policy in cash. Credit terms or credit terms run by a company are usually determined by the type of business in which the company is involved, or in other words, these credit terms are closely related to the type or nature of the goods being traded (how the goods are transported and used). Credit sales are one way to increase sales other than by increasing the quality of goods, reducing prices, giving special discounts or special prices by selling goods or services for which payments are paid in instalments, meaning that consumers buy goods with payments in the future after a certain period of time (Kasmir, 2010: 231). According to Suparwoto (2014: 167), instalment sales or instalment sales are sales whose payments are made in stages in the future. Instalment sales are made with the aim of increasing sales volume, which in turn will also increase company profits.

According to Harmono (2011: 2011), credit standards are the determination of the criteria for guaranteed credit given to customers and the extent of creditworthy of being given, determining the credit standard policy is highly dependent on the subjectivity and objectivity of information obtained a) Character, the ability to pay creditors. b) Capacity, the customer's ability to generate cash flow. c) Capital, the customer's resources. d) Collateral, credit guarantees. e) Condition of Economic, business conditions. Lukman (2011: 256) argues that the credit standing of a company is defined as the minimum criteria that must be fulfilled by a customer before credit can be given, there are several main factors that must be considered by the company if it intends to change the credit standards applied 1) Administrative Costs. 2) Investment in Receivables. 3) Bad debt expenses. 4) Sales Volume. Following is a table of the effects of the use of credit standards on company profits and the changes that result.

Table 1. Effects of Softening Credit Standards on Company Profits and The Changes that Have Resulted

\begin{tabular}{lcc}
\hline \multicolumn{1}{c}{ Information } & Change Up or Down & $\begin{array}{c}\text { Effects on positive (+) or } \\
\text { negative (-) gains }\end{array}$ \\
\hline $\begin{array}{l}\text { Sales volume } \\
\text { Average collection of }\end{array}$ & Ride & + \\
receivables & Ride & - \\
Losses Receivables & Ride & - \\
\hline
\end{tabular}

Source: Lukman (2011)

According to Lukman (2011: 273), a number of techniques for collecting receivables that are usually carried out by companies when the customer or buyer has not paid up to the specified time are as follows by letter, telephone, personal visit, juridical action. According to Seomarso (2008: 230), profit is the difference between income over expenses related to business activities, when the burden is greater than income, the difference is called loss, profit/loss is the result of periodic calculations. According to Hanafi and Halim in Ade (2006, p.20) states that earnings growth is 
influenced by several factors including the size of the company, company age, level of leverage, level of sales, changes in past earnings.

The Vion City Probolinggo store is a branded bag store that applies a credit bag sales system in its sales strategy. The credit sales activity is expected to increase sales volume and will result in increased profits. However, even though the credit policy has been implemented, a problem still arises, namely, the problem of uncollectible receivables, which affects the company's financial condition. For this reason, we need to know about the ability of Toko Vion Kota Probolinggo to manage the quality of receivables and the success of the collection of receivables in a given period.

\section{RESEARCH METHODS}

This type of research used in compiling this research is to use descriptive research conducted with a quantitative approach. Descriptive with quantitative approach emphasizes the numbers so that information from the company can be measured using certain formulas, secondary data in the form of financial statements for the period of 2017 to 2019 are analyzed using analysis of activity ratios to measure the financial condition of the company's receivables, then described accordingly with the results of calculating the formulas used. The population in this study is the Vion Shop Probolinggo Financial Statements (Balance Sheet), which contains information about recording the number of accounts receivable from customers from 2017 to 2019. The sample in this study is the last 3 (three) years financial statements, from 2017 to by 2019 which will be analyzed using activity ratio analysis to find out the results/level of effectiveness of receivables management in increasing the profit of the Vion City Store in Probolinggo, effective/profitable or ineffective/unlucky. Researchers used to interview and documentation of data collection techniques. The document study is a complement to the use of interview and observation methods in this research. With this data collection technique, the researcher obtained data from the financial statements (balance sheets) of the last 3 (three) years starting from 2017 to 2019. From the total data collected will be analyzed quantitative, which will later be described as guidelines for solving problems faced by the Vion City Store Probolinggo. The method used to determine the development of management of receivables at the Vion City Probolinggo Store is to use information through written data from the company in the form of data on corporate financial statements as well as oral information regarding the practice of corporate receivables management. The condition of company receivables is used to determine or assess the management of company receivables.

According to J. Fred Weston in Kasmir (2010: 110) Activity Ratio, is the ratio used to measure the effectiveness of a company is using its assets or the ratio used to measure the level of efficiency in the utilization of company resources, activity ratios are also used for assessing the company's ability to carry out daily activities, types of financial ratios, namely 1) Receivable Turnover, is a ratio used to measure how long the collection of receivables during a period, or how many times the funds invested in these receivables revolve in one period. The accounts receivable turnover ratio gives an understanding of the quality of the receivables and the success of the collection of receivables can be calculated by Receivable Turnover (RTO) is credit sales / on average of Receivables. 2) Days of Receivable, the results of this calculation show the number of days (how many days) the average debt cannot be billed, calculated by DOR = (Average Receivables $/$ On average Receivables) x 360 or DOR $=$ Number of Days in 1 Year / Receivables turnover

\section{RESULTS AND DISCUSSION}

Based on the results of interviews with informants and the research conducted, the researchers then describe the findings in the field based on the focus of the research, namely the analysis of the effectiveness of accounts receivable management in increasing profits through the application of 
sales policies on credit bags that include credit policies, credit standards, credit analysis, credit requirements, the policy on collecting receivables as well as the techniques of collecting receivables at the Vion Shop in Probolinggo City. Documentation of secondary data of Vion Toko Probolinggo City in the form of financial statements (balance sheet) of the last 3 (three) years from 2017 to 2019 which contains information on recording the number of accounts receivable from customers analyzed quantitatively using analysis of activity ratios to measure the company's financial condition, to find out whether the analysis of accounts receivable management at the Probolinggo City Vion Store is effective/profitable or ineffective/unprofitable which will be described in accordance with the results of the calculation of the activity ratio formula used.

Credit standards in Vion City Probolinggo Stores are prospective customers who must meet the 5C analysis, namely Character, Capacity, Capital, Condition. In addition, there are two things that are no less important in assessing future conditions when providing goods/bags credit, namely Administrative costs, administrative costs included here are the mobilization costs incurred by the Vion City Store in Probolinggo in the process of collecting receivables such as the cost of buying pulses to call/contact the customer, transport costs for personal visits to the customer's home. Investment in Receivables, Toko Vion Kota Probolinggo provides reserve capital to balance the company's financial condition because part of the capital is already embedded in the receivables. Collateral.

The Sales Department analyzes prospective customers at the Vion City Store Probolinggo conducted with 5C analysis and then records the customer's book, the sales department communicates to the store owner for further decision making. The credit requirements for Toko Vion Kota Probolinggo are a) Credit Guarantee, namely to take credit for goods, customers only need to show their ID card or work identity card to record their name, home address or place of work on the customer's book. b) Cash Discount / Cash Discount is applied if the customer is able to pay off credit before the due date, for example, credit that should be repaid three times, the customer is able to pay off the second instalment, then the Vion City Store Probolinggo provides a cash discount of $5 \%$ of the price of goods/credit value of goods. c) Credit Period, i.e. changes in credit period are applied if the customer is able to pay off the credit before the due date, for example, a credit that should be repaid for 90 (ninety) days but there are some customers who ask to repay the credit for 45 (forty-five) days. This greatly affects the profitability of the store because there is an opportunity to accelerate the collection of receivables into cash. 
E-ISSN : 2549-5992, P-ISSN : 2088-0944

Available online at:

http://ejournal.stiewidyagamalumajang.ac.id/index.php/wiga

Table 2. Vion Store Credit Sales Period 2017 - 2019

(in thousands of rupiah)

\begin{tabular}{|c|c|c|c|c|c|c|c|c|c|c|}
\hline \multirow[b]{2}{*}{ No } & \multirow[b]{2}{*}{ Month } & \multicolumn{3}{|c|}{2017} & \multicolumn{3}{|c|}{2018} & \multicolumn{3}{|c|}{2019} \\
\hline & & $\begin{array}{l}\text { Credit } \\
\text { sales }\end{array}$ & $\begin{array}{l}\text { Settle } \\
\text { ment } \\
\text { of } \\
\text { Receiv } \\
\text { ables } \\
\text { (Befor } \\
\text { e } \\
\text { Maturi } \\
\text { ty) } \\
\end{array}$ & $\begin{array}{l}\text { Final } \\
\text { Receiv } \\
\text { ables } \\
\text { (After } \\
\text { Maturi } \\
\text { ty) }\end{array}$ & $\begin{array}{l}\text { Credit } \\
\text { sales }\end{array}$ & $\begin{array}{l}\text { Settleme } \\
\text { nt of } \\
\text { Receivab } \\
\text { les } \\
\text { (Before } \\
\text { Maturity } \\
\text { ) }\end{array}$ & $\begin{array}{l}\text { Final } \\
\text { Receiv } \\
\text { ables } \\
\text { (After } \\
\text { Maturi } \\
\text { ty) }\end{array}$ & $\begin{array}{l}\text { Credit } \\
\text { sales }\end{array}$ & $\begin{array}{l}\text { Settle } \\
\text { ment } \\
\text { of } \\
\text { Receiv } \\
\text { ables } \\
\text { (Befor } \\
\text { e } \\
\text { Maturi } \\
\text { ty) }\end{array}$ & $\begin{array}{l}\text { Final } \\
\text { Receiv } \\
\text { ables } \\
\text { (After } \\
\text { Maturi } \\
\text { ty) }\end{array}$ \\
\hline & $\begin{array}{l}\text { Accounts } \\
\text { Receivable } \\
\text { Early }\end{array}$ & & & & & & 4.645 & & & 9.425 \\
\hline 1 & January & 11.190 & 11.050 & 140 & 7.755 & 7.055 & 700 & 11.500 & 10.100 & 1.400 \\
\hline 2 & February & 11.110 & 10.500 & 610 & 6.650 & 6.050 & 600 & 7.750 & 7.050 & 700 \\
\hline 3 & March & 8.810 & 8.450 & 360 & 10.130 & 9.130 & 1.000 & 10.200 & 9.750 & 450 \\
\hline 4 & April & 12.020 & 11.185 & 835 & $11.581,5$ & $10.181,5$ & 1.400 & 3.390 & 3.290 & 100 \\
\hline 5 & May & 12.060 & 11.780 & 280 & 8.860 & 8.110 & 750 & 3.332 & 3.154 & 178 \\
\hline 6 & June & 4.450 & 4.250 & 200 & 7.760 & 7.085 & 675 & 4.410 & 4.160 & 250 \\
\hline 7 & July & 5.450 & 5.200 & 250 & - & - & - & 4.100 & 3.900 & 200 \\
\hline 8 & August & 10.000 & 9.590 & 410 & 11.130 & 10.130 & 1.000 & 5.000 & 4.590 & 410 \\
\hline 9 & September & 11.160 & 10.620 & 540 & 11.380 & 10.130 & 1.250 & 8.000 & 7.640 & 360 \\
\hline 10 & October & 11.450 & 10.630 & 820 & 11.020 & 10.070 & 950 & 5.000 & 4.550 & 450 \\
\hline 11 & November & 4.450 & 4.250 & 200 & 8.840 & 8.040 & 800 & 7.500 & 6.800 & 700 \\
\hline \multirow[t]{2}{*}{12} & December & - & - & - & 3.390 & 3.090 & 300 & 7.500 & 6.825 & 675 \\
\hline & Total & 102.150 & 97.505 & 4.645 & $98.496,5$ & $89.071,5$ & 9.425 & 77.682 & 71.809 & 5.873 \\
\hline
\end{tabular}

Source: Vion Shop

Table 3. Vion Store Profit Report Period 2017 - 2019

(In Rupiah)

\begin{tabular}{lccr}
\hline \multicolumn{1}{c}{ Components of Income } & \multicolumn{3}{c}{ Year } \\
\cline { 2 - 4 } Statement & $\mathbf{2 0 1 7}$ & $\mathbf{2 0 1 8}$ & \multicolumn{1}{c}{$\mathbf{2 0 1 9}$} \\
\hline Pendapatan Usaha & 97.505 .000 & 89.071 .500 & 71.809 .000 \\
Pendapatan dari Luar Usaha & & & \\
Jumlah Pendapatan & & & 258.385 .500 \\
Biaya Operasi & & & \\
Biaya Umum & 4.500 .000 & 7.000 .000 & 9.000 .000 \\
Biaya Administrasi & 7.500 .000 & 10.500 .000 & 11.000 .000 \\
Biaya Lainnya & 3.000 .000 & 5.000 .000 & 6.700 .000 \\
Jumlah Biaya Operasi & & & 64.200 .000 \\
Laba sebelum pajak & & & 194.185 .500 \\
Pajak & & & $3.530 .645,45$ \\
Laba setelah pajak & & & $190.654 .854,55$ \\
\hline Source: Vion Shop
\end{tabular}

Source: Vion Shop 
Table 4. Vion's Shop Balance Period 2017 - 2019 (In Rupiah)

\begin{tabular}{|c|c|c|c|}
\hline \multirow{2}{*}{ Information } & \multicolumn{3}{|c|}{ Year } \\
\hline & 2017 & 2018 & 2019 \\
\hline \multicolumn{4}{|l|}{ Assets: } \\
\hline \multicolumn{4}{|l|}{ Current Assets } \\
\hline Cash & $50.000 .000,00$ & $89.071 .500,00$ & $71.809 .000,00$ \\
\hline \multicolumn{4}{|l|}{ Bank } \\
\hline Accounts Receivable & $4.645 .000,00$ & $9.425 .000,00$ & $5.873 .000,00$ \\
\hline Stock & $42.000 .000,00$ & $35.000 .000,00$ & $40.000 .000,00$ \\
\hline Prepaid expenses & - & - & - \\
\hline \multicolumn{4}{|l|}{ Fixed Assets } \\
\hline Computer & $5.000 .000,00$ & $4.250 .000,00$ & $3.613 .000,00$ \\
\hline A4 printer & $1.500 .000,00$ & $1.225 .000,00$ & $1.000 .000,00$ \\
\hline Building & $200.000 .000,00$ & $200.000 .000,00$ & $200.000 .000,00$ \\
\hline Motorcycle & $30.000 .000,00$ & $25.000 .000,00$ & $20.000 .000,00$ \\
\hline Accumulated depreciation & $5.000 .000,00$ & $5.000 .000,00$ & $5.000 .000,00$ \\
\hline Total Assets & $328.145 .000,00$ & $358.971 .500,00$ & $337.295 .000,00$ \\
\hline \multicolumn{4}{|l|}{ Liability } \\
\hline Current liabilities & - & - & - \\
\hline Accounts payable & - & - & - \\
\hline Tax payable & - & - & - \\
\hline Other Debts & - & - & - \\
\hline Total Current Debt & - & - & - \\
\hline Long-term debt & - & - & - \\
\hline Bank debt & $50.000 .000,00$ & $38.748 .000,00$ & $18.531 .000,00$ \\
\hline \multicolumn{4}{|l|}{ Third-Party Debts } \\
\hline \multicolumn{4}{|l|}{ Total Long-Term Debts } \\
\hline Paid-up capital & $278.145 .000,00$ & $320.223 .500,00$ & $318.764 .000,00$ \\
\hline Total Capital & $328.145 .000,00$ & $358.971 .500,00$ & $337.295 .000,00$ \\
\hline Number of Liabilities & $328.145 .000,00$ & $358.971 .500,00$ & $337.295 .000,00$ \\
\hline
\end{tabular}

This ratio is to measure the number of times the funds invested in these accounts revolve in one period. Receivables turnover ratio provides an understanding of the quality of receivables and the success of receivables collection. Here are the results of the calculation of the level of receivable turnover (Receivable Turnover / RTO) Vion City Probolinggo Shop for the period 2017 - 2019 are as follows:

Table 5. Receivable Turnover (RTO)

\begin{tabular}{ccccccccccc}
\hline Year & $\begin{array}{c}\text { Initial } \\
\text { Receivables } \\
(\mathbf{R p})\end{array}$ & $\begin{array}{c}\text { Credit sales } \\
(\mathbf{R p})\end{array}$ & $\begin{array}{c}\text { Final } \\
\text { Receivables } \\
(\mathbf{R p})\end{array}$ & $\begin{array}{c}\text { Average } \\
\text { Receivables } \\
(\mathbf{R p})\end{array}$ & RTO & $\begin{array}{c}\text { Infor } \\
\text { matio } \\
\mathbf{n}\end{array}$ & $\begin{array}{c}\text { Chan } \\
\text { ges } \\
\text { that } \\
\text { Happ } \\
\text { ened }\end{array}$ \\
\hline 2017 & - & 102.150 .000 & 4.645 .000 & 2.322 .500 & 44 & Kali & & \\
2018 & 4.645 .000 & 98.496 .500 & 9.425 .000 & 7.035 .000 & 14 & Kali & $\downarrow(\mathrm{T})$ & Turun \\
2019 & 9.425 .000 & 77.682 .000 & 5.873 .000 & 7.649 .000 & 10 & Kali & $\downarrow(\mathrm{T})$ & Turun \\
\hline Source: processed data & & & & & & & & &
\end{tabular}


From table 5 above shows that the performance of TokoVion City Probolinggo Receivable Turnover (RTO) in the 2017 - 2019 period has always decreased. In 2017 the RTO was 44 times, decreased dramatically in 2018 the RTO became 14 times and decreased again in 2019 to 10 times. The performance of RTO Vion Toko Probolinggo City reached the lowest point occurred in 2019, which is ten times, with an average of very high receivables amounting to Rp. 7,649,000. Broadly speaking, the performance of receivable turnover (RTO) Vion Stores in the City of Probolinggo for the period 2017 - 2019 has always decreased. This happens because the average receivables are very high, so it affects the level of investment in receivables (over-investment) and working capital investment to manage receivables.

Table 6. Table of Receivable Turnover (RTO) Realization Rate

\begin{tabular}{|c|c|c|c|c|c|}
\hline Year & \multicolumn{2}{|c|}{$\begin{array}{c}\text { Benchmark / } \\
\text { Standard }\end{array}$} & $\begin{array}{c}\text { Realization of Vion Shop } \\
\text { RTO }\end{array}$ & Information & $\begin{array}{c}\text { Changes that } \\
\text { Happened }\end{array}$ \\
\hline 2017 & 15 & Time & 44 time & & - \\
\hline 2018 & 15 & Time & 14 time & $\downarrow$ (down) & down \\
\hline 2019 & 15 & Time & Ten-time & $\downarrow$ (down) & down \\
\hline
\end{tabular}

Source: processed data

From table 6, it can be seen that the performance of Receivable Turnover (RTO) Vion Stores in Kota Probolinggo is ineffective/unprofitable. From 2017 - 2019, there has always been a decrease due to the average receivables that are always increasing. It is recommended that accounts receivable revolve 15 times according to the guidelines in the accounts receivable turnover ratio according to Kasmir (2014: 187)

This ratio serves to determine the average days needed to collect receivables and convert it to cash, showing the number of days (how many days) the average debt cannot be billed, can later be used as a guideline for determining the number of days specified in the company's credit standards. The results of the calculation of Average Receivable Collection (Days of Receivable / DOR) Vion City Probolinggo.

Table 7. Average Receivable Collection (Days of Receivable / DOR)

\begin{tabular}{cccccccc}
\hline Year & $\begin{array}{c}\text { Average } \\
\text { Receivables }(\text { Rp) }\end{array}$ & RTO & DOR & Information & $\begin{array}{c}\text { Changes that } \\
\text { Happened }\end{array}$ \\
\hline 2017 & 2.322 .500 & 44 & Time & 8 & Day & & \\
2018 & 7.035 .000 & 14 & Time & 26 & Day & Up & + \\
2019 & 7.649 .000 & 10 & Time & 36 & Day & Up & + \\
\hline
\end{tabular}

Source: processed data

From table 7 it can be seen that the results of the calculation of the average collection of receivables (Days of Receivable / DOR) at the Vion City Store Probolinggo from 2017 to 2019 always experience an increase. In 2017 the DOR was 8 days, 2018 in 26 days and in 2019 is 36 days. The lowest level of calculation of receivables collection (Days of Receivable / DOR) at Vion City Probolinggo Stores occurred in 2017, where the day needed to convert receivables into cash is eight days.

Table 8. Table of Realization of Average Days of Receivable (DOR)

\begin{tabular}{llll}
\hline Tahun & \multicolumn{2}{l}{ Realization / DOR } & Changes that Happened \\
\hline 2017 & 8 & Time & + \\
\hline 2018 & 26 & Time & + \\
\hline 2019 & 36 & Time & + \\
\hline Source: processed data & &
\end{tabular}

Source: processed data 
From table 8 it is known that the average level of calculation of receivables (DOR) at the Probolinggo City Vion Shop shows that the Probolinggo City Vion Store in each period requires an additional average day of receivables collection. Based on the discussion and quantitative analysis in the previous sub-chapter, it can be concluded that the performance of the Receivable Turnover (RTO) level of the Vion Store in Probolinggo City for the period 2017 - 2019 has always decreased. In 2017 the RTO was 44 times, decreased drastically in 2018 the RTO became 14 times and decreased again in 2019 to 10 times. The performance of RTO Vion Toko Probolinggo City reached the lowest point occurred in 2019, which is ten times, with an average of very high receivables amounting to Rp. 7,649,000. 2017 - 2019 always decreases. This happens because the average receivables are very high, so it affects the level of investment in receivables (overinvestment) and working capital investment to manage receivables. The performance of receivable turnover (RTO) at Vion City Probolinggo Stores is ineffective/unprofitable. From 2017 - 2019, there has always been a decrease due to the average receivables that are always increasing. The results of the calculation of the average collection of receivables (Days of Receivable / DOR) at the Vion City Store Probolinggo from 2017 to 2019 always increased. In 2017 the DOR was 8 days, 2018 in 26 days and in 2019 is 36 days.

Table 9. Comparison of 2017 Profit and Loss Statements for 2019

\begin{tabular}{lcccccc}
\hline $\begin{array}{c}\text { Components of } \\
\text { Income }\end{array}$ & \multicolumn{3}{c}{ Year } & \multicolumn{3}{c}{$\begin{array}{c}\text { Percentage of Earnings } \\
\text { Sta) }\end{array}$} \\
\cline { 2 - 7 } \multicolumn{1}{c}{ Statement } & $\mathbf{2 0 1 7}$ & $\mathbf{2 0 1 8}$ & $\mathbf{2 0 1 9}$ & $\mathbf{2 0 1 7}$ & $\mathbf{2 0 1 8}$ & $\mathbf{2 0 1 9}$ \\
\hline $\begin{array}{l}\text { Operating } \\
\text { revenues }\end{array}$ & 97.505 .000 & 89.071 .500 & 71.809 .000 & 37,74 & 34,47 & 27,79 \\
$\begin{array}{l}\text { Income from } \\
\text { Foreign Business }\end{array}$ & & & & & & \\
Total Income & & & 258.385 .500 & & & \\
$\begin{array}{l}\text { Operating costs } \\
\text { General Charges }\end{array}$ & 4.500 .000 & 7.000 .000 & 9.000 .000 & 23,36 & 35,05 & 41,59 \\
$\begin{array}{l}\text { Administrative } \\
\text { costs }\end{array}$ & 7.500 .000 & 10.500 .000 & 11.000 .000 & & & \\
Other costs & 3.000 .000 & 5.000 .000 & 6.700 .000 & & & \\
Total Operating & & & 64.200 .000 & & & \\
Costs & & & & & & \\
\hline
\end{tabular}

Source: Vion Shop

From table 9 above it can be seen that the percentage of profits from 2017 to 2019 always decreases to $27.79 \%$ in 2019 this is because the average receivables from 2017 to 2019 always increase so that it affects operating costs (investment) which have increased from 2017 to 2019.

\section{CONCLUSION}

The receivable turnover (RTO) level of Vion Stores in Probolinggo City in the 2017 - 2019 period has always decreased. In 2017 the RTO was 44 times, decreased drastically in 2018 the RTO became 14 times and decreased again in 2019 to 10 times. The lowest RTO performance occurred in 2019, which is ten times, with an average of very high receivables amounting to Rp. 7,649,000. Broadly speaking, the performance of receivable turnover (RTO) Vion Stores in the City of Probolinggo for the period 2017 - 2019 has always decreased. The performance of receivable turnover (RTO) at Vion City Probolinggo Stores is ineffective/unprofitable. The results of the calculation of the average collection of receivables (Days of Receivable / DOR) at the Vion City Store Probolinggo from 2017 to 2019 always increased. In 2017 the DOR was 8 days, 2018 in 26 days and in 2019 is 36 days. The lowest level of calculation of receivables collection (Days of Receivable / DOR) at Vion City Probolinggo Stores occurred in 2017, where the day needed to convert receivables into cash is eight days. The percentage of profit from 2017 to 2019 always 
decreases to $27.79 \%$ in 2019 this is because the average receivables from 2017 to 2019 always increase, so it affects the operating costs (investment) which have increased from the year 2017 to 2019.

\section{REFERENCE}

Aaker, D. (2013). Aaker On Branding. PT Gramedia Pustaka Utama: Jakarta.

Agusli, D. dan Yohanes, S. K. (2013). Analisa Dimensi Ekuitas Merek Terhadap Minat Beli Konsumen Midtown Hotel Surabaya. Jurnal Manajemen Pemasaran Petra. (Online). Vol.1, No. 2:1-8. (http://studentjournal.petra.ac.id). Diakses 27 Februari 2017.

Iriani, N. I. (2011). Pengaruh Dimensi Brand Equity (Ekuitas Merek) Terhadap Keputusan Pembelian Kartu Seluler Telkomsel di Kota Malang. Jurnal Aplikasi Manajemen. (Online). Vol.9, No: 2. (http://jurnaljam.ub.ac.id). Diakses 17 Februari 2017

Kartajaya, H. (2010). Brand Operation. Erlangga Group: Jakarta.

Kotler, P. dan Kevin, L. K. (2009). Manajemen Pemasaran. Erlangga: Jakarta.

Kuncoro, M. (2007). Metode Kuantitatif Teori dan Aplikasi Untuk Bisnis dan Ekonomi. UPP STIM YKPN: Yogyakarta.

Massie, P. V. (2013). Ekuitas Merek Pengaruhnya Terhadap Keputusan Pembelian XL Data Service Di Kota Manado. Jurnal EMBA. (Online). Vol.1, No. 4:1474-1481. (http://ejournal.unsrat.ac.id). Diakses 12 Februari 2017.

Nugroho, Y. A. (2011). Its Easy Olah Data Dengan SPSS. Skripta: Yogyakarta.

Pornnarat. B. et al. (2014). Brand Equity Affecting Purchasing Decision Process Of Doughnut From The Departement Store In Bangkok. Prosiding Tahunan Tokyo Bisnis Penelitian Conference (Online). (www.wbiwordconpro.com). Diakses 27 Februari 2017

Santoso. C. R. dan Ella, C. (2014). Analyzing The Impact Of Brand Equity Toward Purchase Intentention In Outomotive Industry : A Case Study Of Abc In Surabaya. iBuss Management. (Online). Vol.2, No.2:29-39. (http://studentjournal.petra.ac.id). Diakses 19 Februari 2017.

Sugiyono. (2009). Metode Penelitian Bisnis. CV Alfabeta: Bandung.

Tandjung, J. W. (2004). Marketing Management Pendekatan Pada Nilai-Nilai Pelanggan. Bayumedia Publishing: Malang.

Tjiptono. F. (2005). Brand Management and Strategy. Andi Publisher: Yogyakarta. 